\title{
Composition and exhalation flux of gases from mud volcanoes in Taiwan
}

\author{
Tsanyao Frank Yang · Gao-Hua Yeh · Ching-Chou Fu · Cheng-Chen Wang \\ Te-Fang Lan · Hsiao-Fen Lee · Cheng-Hong Chen · Vivek Walia · Quo-Cheng Sung
}

\begin{abstract}
Many mud volcanoes are distributed along the tectonic sutures in southern Taiwan and can be divided into five zones based on their relative positions in different tectonic domains. Most active mud volcanoes are exhaling methane-dominated gases. Nevertheless, some gases show unusual carbon dioxide-dominated and/or nitrogen-excess compositions. This implies that there are multiple sources for the gas compositions of mud volcanoes in Taiwan. For better understanding the total amount of exhalation gases and its flux, the gas flow and compositions were continuously measured in the interval of two minutes at Chung-lun (CL) bubbling mud pool for a few months. The major compositions of gases exhaling from this site were $75 \sim 90 \%$ of $\mathrm{CO}_{2}$ and $5 \sim 12 \%$ of $\mathrm{CH}_{4}$. The amount of gases exhaling from the mud pool can be estimated to be about 1.4 ton/year for $\mathrm{CH}_{4}$ and 28 ton/year for $\mathrm{CO}_{2}$, respectively. The preliminary results of exhaling gas flux from the major vents of representative active mud volcanoes, yielded an estimated total $\mathrm{CH}_{4}$ output of the mud volcanoes in Taiwan of ca. 29 ton/year during quiescent period.
\end{abstract}

Received: 20 October 2003 / Accepted: 20 April 2004

Published online: 2 July 2004

(C) Springer-Verlag 2004

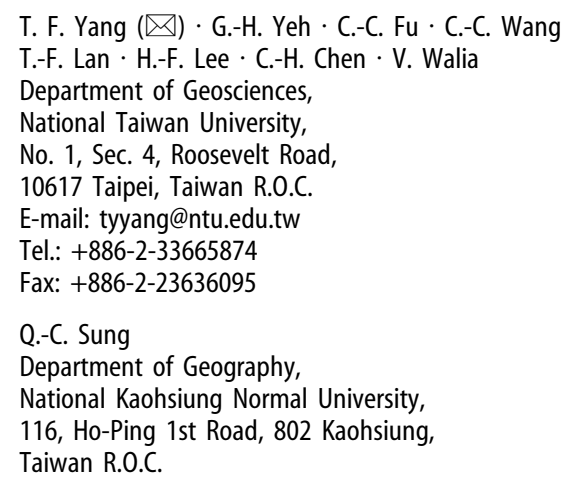

Keywords Mud volcano - Exhalation .

Methane - Taiwan

\section{Introduction}

Recent studies reveal that mud volcanoes may be the most important pathway for degassing of deeply buried sediments, and are one of the remarkable natural sources for atmospheric methane (e.g., Dimitrov 2002; Etiope and Klusman 2002; Kopf 2002; Milkov and others 2003). Natural gases, mainly methane and carbon dioxide, are continuously emitted from mud volcanoes and constitute an important natural contribution to the atmosphere carbon budget. Estimation of global flux from mud volcanoes in the world, hence, becomes an interesting topic for discussion of the potential influences on the global climate changes (Judd and others 1997, 2002; Etiope and others 2002; Etiope and Klusman 2002; Kopf 2002; Milkov and others 2003). Therefore, precise quantitative measurements of the discharge of gas through mud volcanoes are very important for such a kind of estimation, although reliable data are usually difficult to obtain due to the episodicity of the mud volcanism (Kopf 2003).

Mud volcanoes are mainly distributed around subduction zones and orogenic belts where lateral tectonic compressional stress is dominant (Yassir 1987; Milkov 2000; Kopf 2002). Many mud volcanoes were also reported in Taiwan on-land (Shih 1967; Wang and others 1988) and offshore (Liu and others 1997; Chow and others 2001). Shih (1967) reported that there were 64 active mud volcanoes in 17 land areas. Five types were classified according to their geomorphologic shapes: mud cone, mud shield, mud maar, mud basin and mud hole.

Gieskes and others (1992) first analyzed the fluids emanating at the surface of the mud volcanoes in Taiwan and suggested that they might be originated from a deep source, which might be from the deeper parts of the accretionary complex. Recent studies of Yeh (2003) and Yeh and others (2004) also supported this hypothesis. Moreover, these authors concluded that different source components and processes were needed to account for the geochemical characteristics of the mud volcano fluids from different tectonic domains. 
Although without eruption of muddy materials, everlasting fire seepage is also an important contribution for the methane budget of atmosphere and hence is included in this study. In this study the authors briefly describe the current situation of active mud volcanoes in Taiwan, and present the gas compositions of representative mud volcanoes and everlasting fire seepages. To better estimate the exhalation flux in-situ continuous quantitative measurement of the selected major vent of mud volcanoes were carried out.

\section{Geological background}

Taiwan is located at the collision zone between Eurasian Plate and Luzon arc (Teng 1990), and develops a typical accretionary prism in southwestern and southeastern Taiwan (Huang and others 1997), where many on-land mud volcanoes are found along the tectonic structure and suture zones. In southwestern Taiwan, many sandstone beds are interbedded in the folded mud stone matrix and considered suitable for the accumulation of natural gases (Hsieh 1972). Hence, many mud volcanoes occur in this area. In contrast, mud volcanoes are less and smaller in eastern Taiwan, because the muddy matrix of the mélange have been seriously sheared by the tectonic stress (Chang and others 2000).

\section{Description of investigated sites}

Following the occurrences described by Shih (1967) and Wang and others (1988), the authors re-visited all the active mud volcanoes and everlasting fire seepages in Taiwan (Fig. 1). They can be grouped into five zones based on their distribution in different tectonic terranes: (1) Chu-kou Fault zone, (2) Gu-ting-keng anticline zone, (3) Chi-shan Fault zone, (4) Coastal Plain zone, and (5) southern Coastal Range zone, respectively.

\section{Chu-kou Fault zone}

Chu-kou (CK) Fault is considered as one of the most potentially re-activated faults in southwestern Taiwan. Chung-lun (CL) mud pool (Fig. 2A), Kuan-tze-ling (KZL) muddy hot spring (Fig. 2B), and Suei-huo-tong-yuan (SHTY) everlasting fire (Fig. 2C) are distributed along CK Fault (Fig. 1). Both the fluids and gases show distinct compositions compared with other areas (Hsieh 2000; Yang and others 2003b; Yeh and others 2004) (Tab. 1) indicating a deep source origin. They are for the first time included and treated as the members of the family of mud volcanoes.

\section{Gu-ting-keng anticline zone}

Many mud volcanoes have been found along the axis of the Gu-ting-keng structural anticline, which is more or less parallel to the direction of the Chi-shan (CS) Fault (Fig. 1).

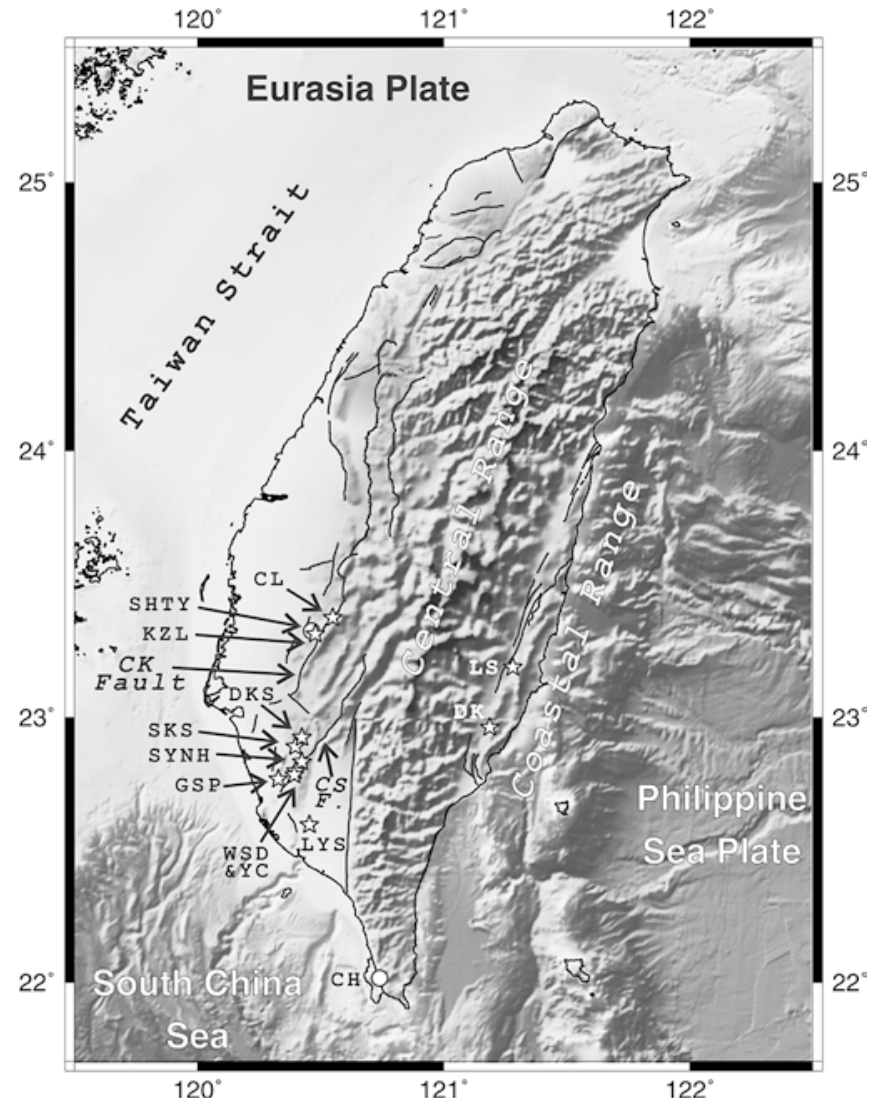

Fig. 1

Distribution of major active mud volcanoes (star symbols) and everlasting fire seepages (circle symbols) in Taiwan. Black lines indicate the active faults

At least five mud volcanoes were reported in the literature (Shih 1967), however, only Da-kung-shuei (DKS) mud pool (Fig. 2D) and Hsiao-kung-shuei (SKS) mud shield (Fig. 2E) are presently active. The major vents of DKS mud pool are located at a pool with a diameter of ca. $50 \mathrm{~m}$ (Fig. 2D), making the study for these bubbling gases inaccessible.

\section{Chi-shan Fault zone}

Chi-shan (CS) Fault is one of the major active faults in southwestern Taiwan (Fig. 1), along which at least five mud volcanoes had been found (Shih 1967). Three major mud volcanoes are still active. Hsin-yang-nyu-hu (HYNH) mud shield (Fig. 2G) and Yang-nyu-hu (YNH) mud pool (not shown in the figure) are located at the northern part of this zone (Fig. 1). Large amounts of muddy materials are continuously erupted with flammable natural gases. Wu-shan-ding (WSD) mud cones (Fig. 2H) are the largest and most well-preserved mud volcanoes in Taiwan. Yanchao (YC) mud pool (Fig. 2I) is a small bubbling pond at the southern end of this zone.

\section{Coastal Plain zone}

Some isolated mud volcanoes occur in the Coastal Plain of southwestern Taiwan. The major active mud volcano is Gung-shuei-ping (GSP) mud shield (Fig. 2F). Only one 

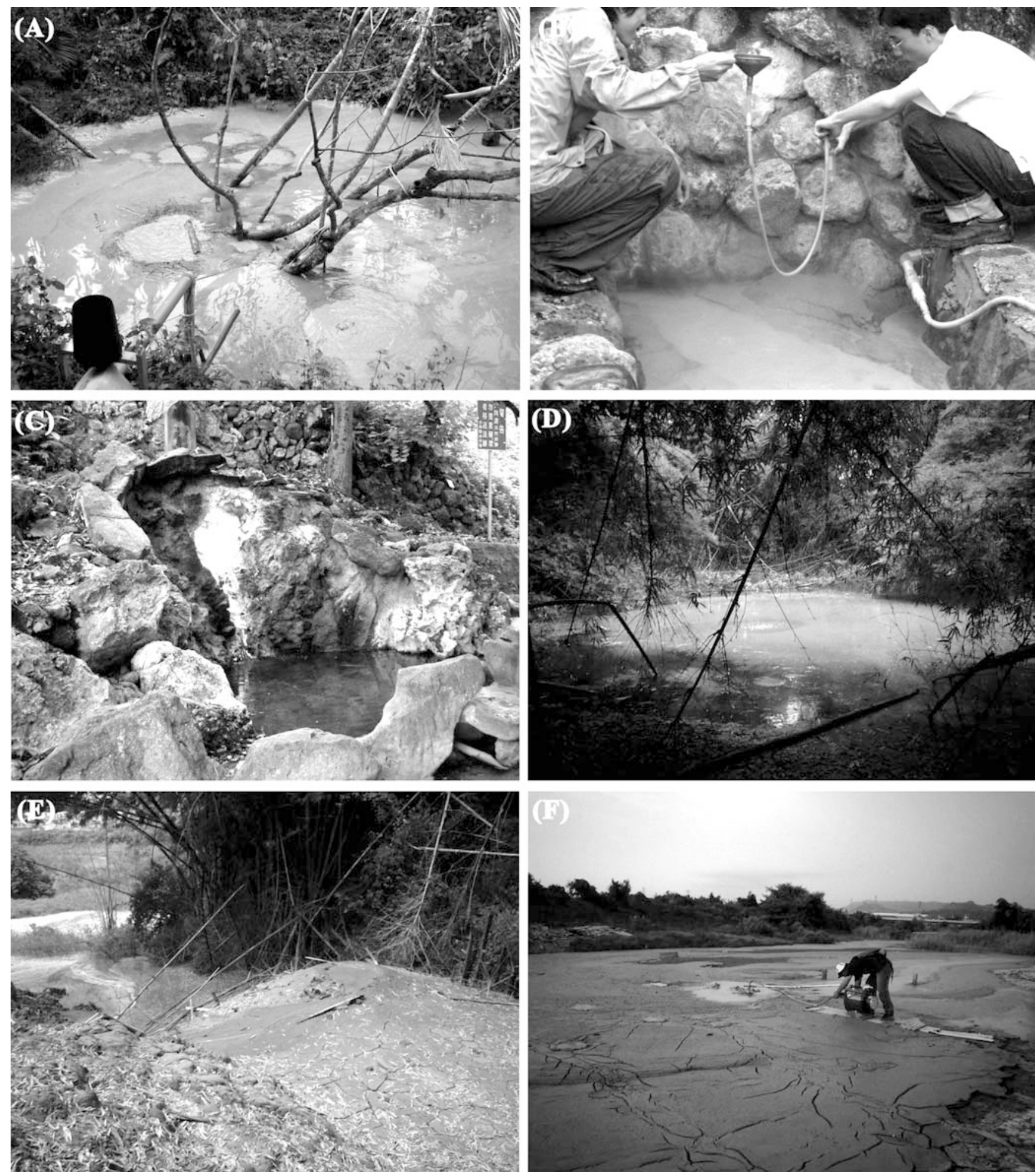

Fig. 2A-F

Photos of representative active mud volcanoes and seepages in Taiwan. See text for detailed description. (A) Chung-lun (CL) mud-basin; (B) Kuan-tze-ling (KZL) muddy hot springs; (C) Suei-huo-tong-yuan (SHTY) everlasting fire; (D) Da-kung-shuei (DKS) mud pool; (E) Hsiaokung-shuei (SKS) mud shield; (F) Gung-shuei-ping (GSP) mud shield

vent is still active at the top of the muddy platform (ca. $350,000 \mathrm{~m}^{2}$ ). Li-yu-shan (LYS) mud shield is another famous mud volcano in this area (Fig. 1). It is very quiet most of time; however, it erupts severely with large amounts of mud (up to $10 \mathrm{~m}$ high) and flammable gases in every few months to years.

Chu-ho $(\mathrm{CH})$ everlasting fire seepage (Fig. 2J) is located at the most southern part of Taiwan (Fig. 1). The seepage covers a naked area of ca. $700 \mathrm{~m}^{2}$, and cannot be classified according to the criteria adopted for mud volcanoes in this study. 

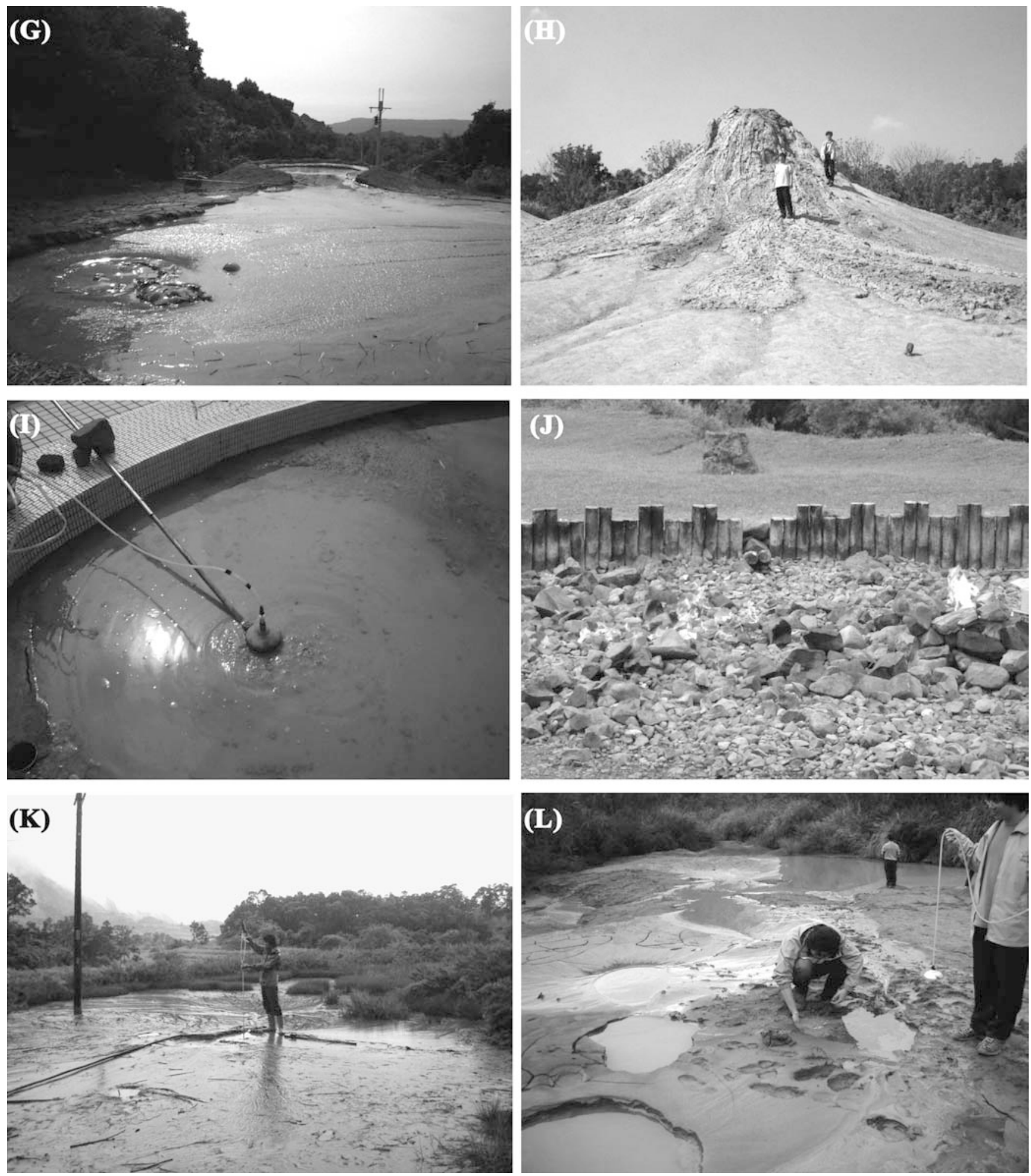

Fig. 2G-L

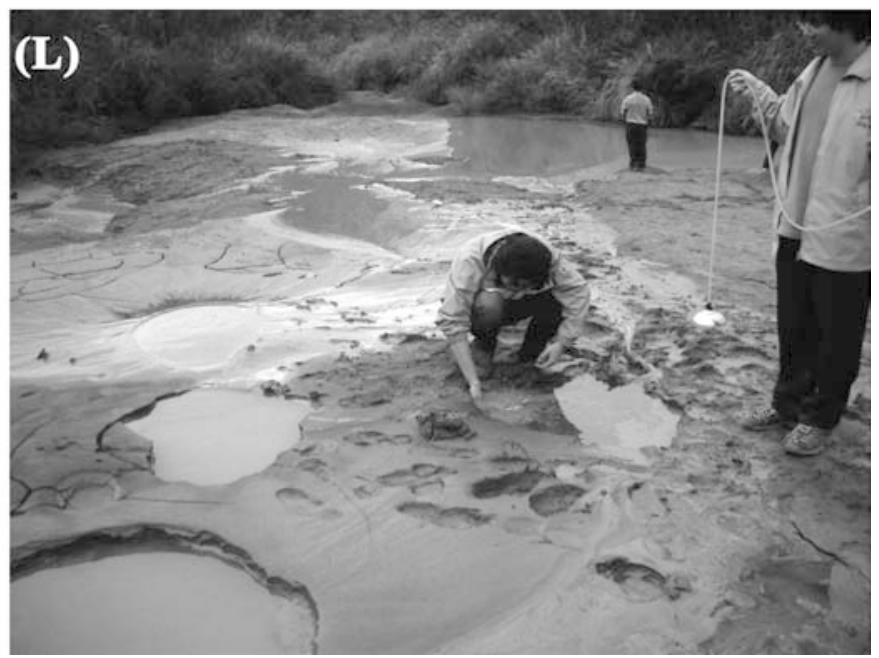

(G)Hsing-yang-nyu-hu (SYNH) mud maar; (H)Wu-shan-ding (WSD) mud cone; (I) Yan-chao (YC) mud pool; (J) Chu-huo (CH) everlasting fire seepage; (K) Luo-shan (LS) mud maar; and (L) Diang-kuang (DK) mud shield

\section{Southern Coastal Range zone}

Two major mud volcanoes are distributed in this zone, namely Luo-shan (LS) mud maar (Fig. $2 \mathrm{~K}$ ) and Diangkuang (DK) mud shield (Fig. 2L). Compared to those in other zones, the viscosity of erupted materials is relatively low and hence, they are unable to form the nice cone shapes (Shih 1967). 
Table 1

Gas compositions of representative mud volcanoes and seepages in Taiwan

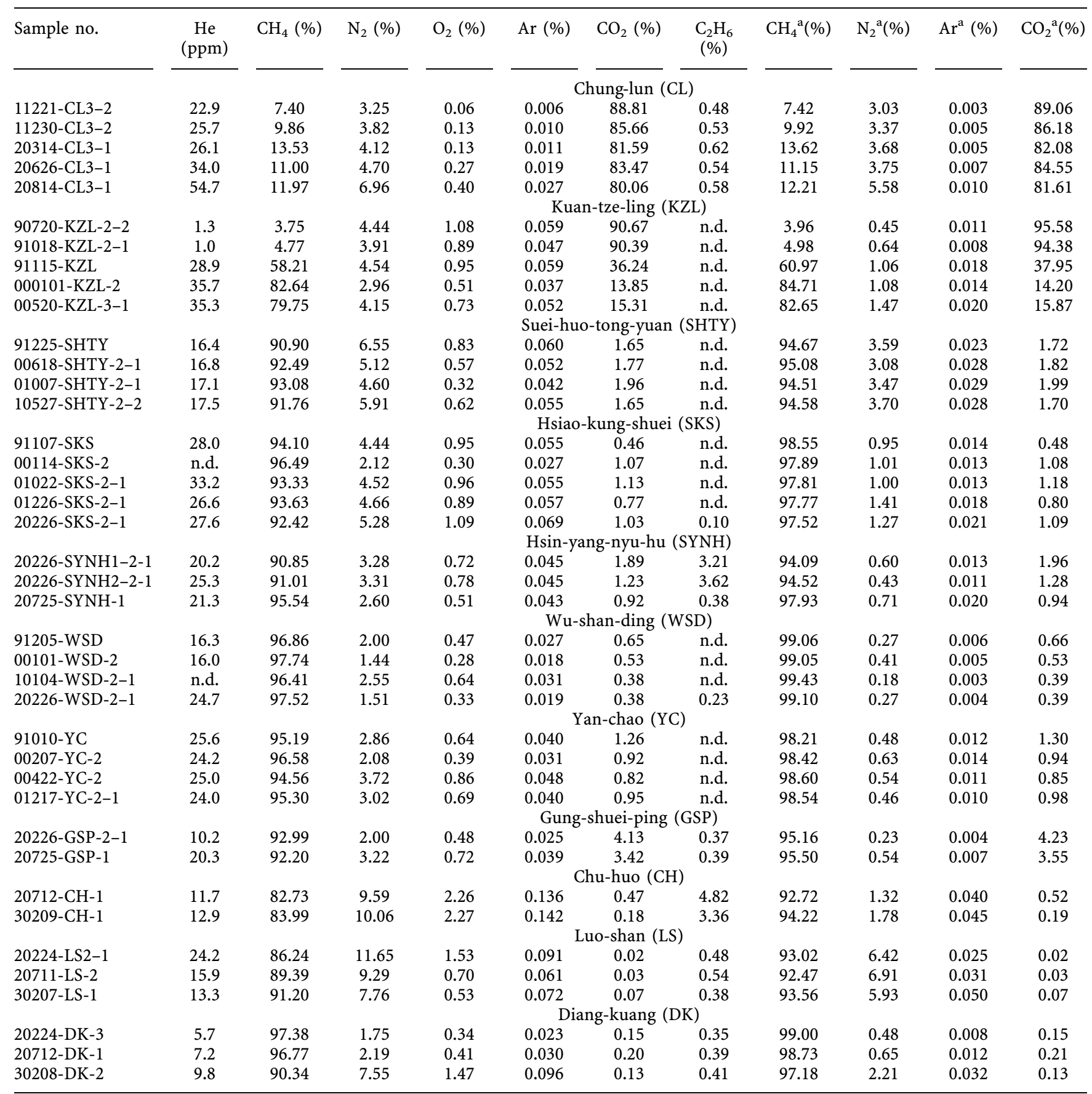

${ }^{a}$ Air corrected compositions. Assuming all $\mathrm{O}_{2}$ are from air contamination, gas compositions can be corrected accordingly and re-normalized to $100 \%$; n.d.=not determined

\section{Experimental methods}

Utilizing pre-evacuated, low permeability glass bottles with two evacuated stopcocks at both ends, representative gas samples were collected by the water replacement technique. The samples then were brought back to the laboratory for gas composition analysis with a quadruple mass spectrometry equipped with Faraday cup and electron multiplier detectors. In general, the overall analytical error is less than $5 \%$ for major components. However, the error may be up to $10-20 \%$ for trace gases like helium and argon. Details of the calibration and correction of the measurements are reported by Yang and others (2004). A monitoring system was set up for continuous gas flow and compositions measurement besides the CL mud pool (Fig. 2A). A stainless funnel $1 \mathrm{~m} \times 1 \mathrm{~m}$ large was installed inversely and fixed at the bottom of the mud pool and covering about one fourth of the gas bubbling area. The 
bubbling gases were then introduced via a PVC pipe into the monitoring station. The gas first passed through a drum-type gas flow meter (Ritter TG10) to calculate gas flow rates (range from 20 to 1,200 liter/hour). Consequently, the gas compositions will be in-situ analyzed by a quadruple mass spectrometer. Detailed setup and analysis of this system has been given by Yang and others (2004). To measure the gas flux of major vents of mud volcanoes, the gases were introduced to a bottle with a preset volume. With a fixed volume the flow rate is calculated from the total time that the bubbling gas displaced the water from the bottle (Etiope and others 2002).

\section{Results and discussion}

\section{Gas compositions and multi-source components}

The gas compositions of representative mud volcanoes and seepages in Taiwan are given in Tab. 1. The authors have conducted the correction of air contamination, assuming all measured oxygen in the sample originated from air during sampling and/or transportation before measurement. Except for CL and KZL samples, the corrected results show that most gases exhaled from "typical" mud volcanoes and everlasting fire seepages are dominant with $\mathrm{CH}_{4}(>92 \%)$, as expected.

It is interesting to note that the "atypical" gas compositions, which are $\mathrm{CO}_{2}$-dominant, only were restricted in those samples related to the CK fault zones, i.e., CL and KZL samples (Fig. 3). As shown in Tab. 1, there obviously exhibits at least two source components for those exhaling gases. One is a $\mathrm{CO}_{2}$-dominant source for $\mathrm{CL}$ gases; the other is a $\mathrm{CH}_{4}$-dominant source for SHTY gases. On this

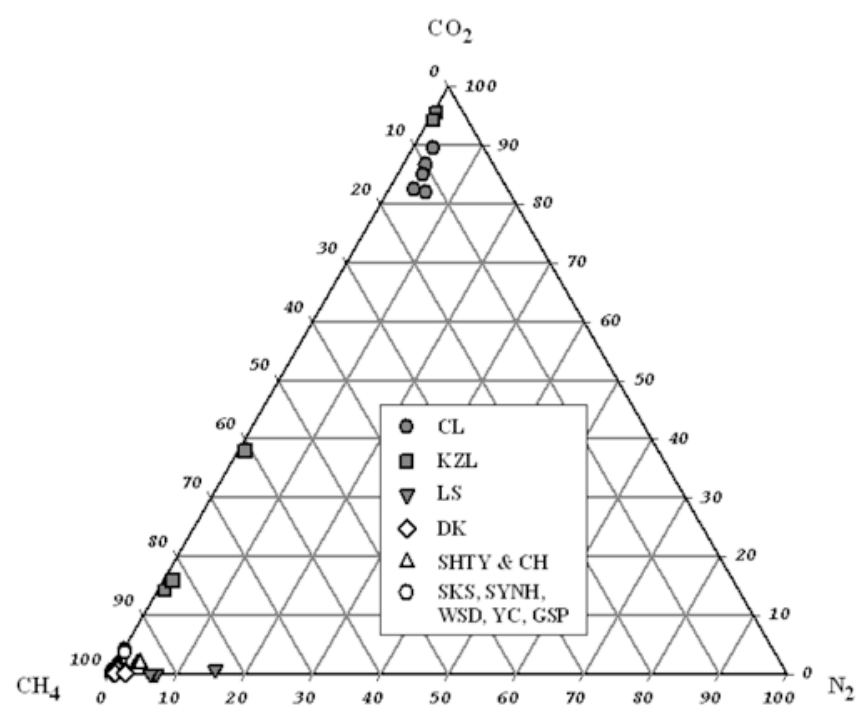

Fig. 3

$\mathrm{CO}_{2}-\mathrm{CH}_{4}-\mathrm{N}_{2}$ compositions of representative mud volcanoes and seepages in Taiwan. The samples can be divided into three groups accordingly. (1) $\mathrm{CH}_{4}$-dominated group: most samples belong to this group; (2) $\mathrm{CO}_{2}$-dominated group: Chung-lun (CL) and Kuan-tze-ling (KZL) samples; and (3) $\mathrm{N}_{2}$-excess group: Luo-shan (LS) samples basis, KZL gases can be regarded as the mixtures of these two components with different proportions.

Available helium isotopic data can help to explain the geochemical characteristics. Yang and others (2003b) reported that the gases exhaled from typical mud volcanoes in southwestern Taiwan usually exhibit low helium isotopic ratios $\left({ }^{3} \mathrm{He} /{ }^{4} \mathrm{He}<0.2 R a\right.$, where $R a$ is the air ratio), which indicates a crustal source in origin. This is consistent with the concept that mud volcanoes are part of the accretionary prism dominated by crustal sediment sources. Nevertheless, bubbling gases from a CL mud pool show much higher helium isotopic ratios $\left({ }^{3} \mathrm{He} /{ }^{4-}\right.$ $\mathrm{He}=5.2 \sim 6.6 R a$ ), implying mantle-derived gas sources. Multiple source reservoirs at different depths, hence, are necessary for the gas exhalation in SW Taiwan. One is a $\mathrm{CO}_{2}$-dominated gas reservoir with a mantle signature (high helium isotopic ratios) at a deeper depth; another is a $\mathrm{CH}_{4}$-dominated gas reservoir with a crustal signature (low helium isotopic ratios) at a shallower depth. As the CK fault is a deep thrust fault, it could be able to provide a pathway for the deep gases to migrate toward the surface (Yang and others 2003b).

In addition to the anomalously high $\mathrm{CO}_{2}$ contents, some samples do show unusual nitrogen-excess compositions after air correction (Tab. 1 and Fig. 3), especially LS samples. The excess nitrogen could be due to biogenic and/or thermal genetic processes. Further nitrogen isotopic analysis is necessary to constrain its origin.

In terms of the $\mathrm{N}_{2}-\mathrm{He}-\mathrm{Ar}$ triangular plot (Fig. 4), it is clear that most typical mud volcano samples fall into the mixing trend between the crustal component (high $\mathrm{He} / \mathrm{Ar}$ and low $\mathrm{N}_{2} / \mathrm{He}$ ratios) and air (and/or groundwater) component (extremely low $\mathrm{He} / \mathrm{Ar}$ and high $\mathrm{N}_{2} / \mathrm{He}$ ratios). Those abnormal samples (especially CL samples), however, fall in the trend between the magmatic component (high $\mathrm{N}_{2} / \mathrm{He}$,

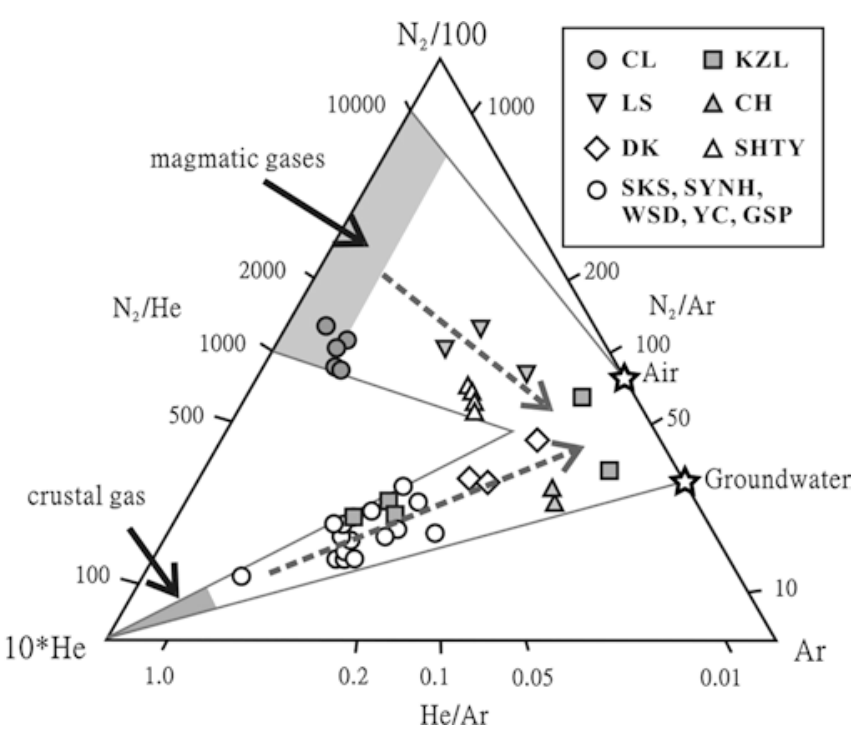

Fig. 4

$\mathrm{N}_{2}$-He-Ar compositions of representative mud volcanoes and seepages in Taiwan. Two mixing trends can be recognized. One is air and/ or groundwater components mixed with crustal gas component; the other, nevertheless, is mixed with magmatic gas component 


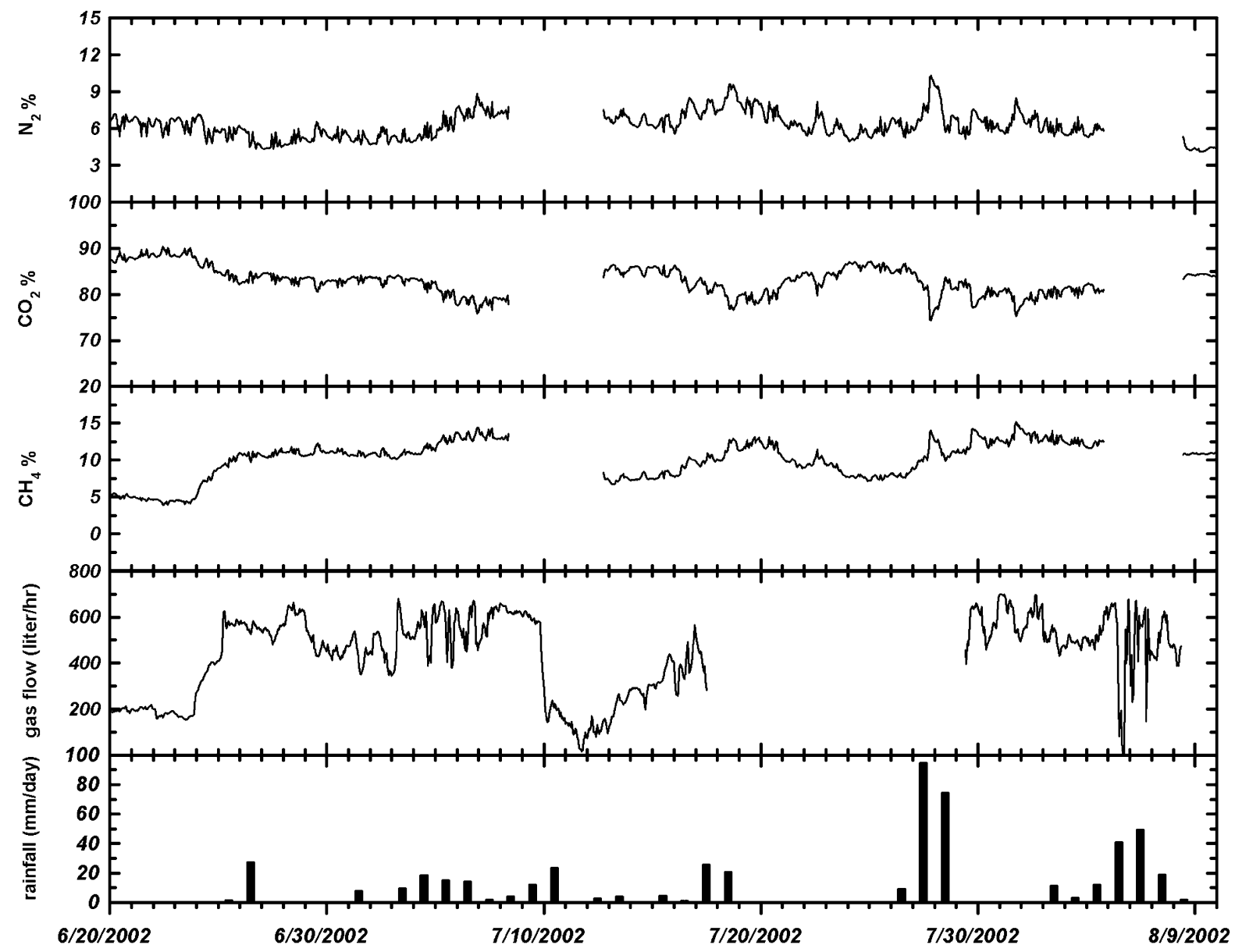

Fig. 5

Variations of composition and flow rate of gases exhaling from the CL mud pool

$\mathrm{He} / \mathrm{Ar}$ and $\mathrm{N}_{2} / \mathrm{Ar}$ ratios) and the air (and/or groundwater) component. Interestingly the LS samples in the Southern Coastal Range zone also fall in this mixing trend. Note that such results are consistent with the high helium isotopic ratios for the LS samples (Yang and others 2003a).

\section{Estimation of gas flux}

Figure 5 shows the variations of gas compositions and flux of the CL mud pool measured from late June, 2002 to early August, 2002. It is clear that the gas flux and compositions were not affected by the local rainfall, although the gas composition and flux varied significantly. Major constituents of gases exhaling from this site were $75 \sim 90 \%$ of $\mathrm{CO}_{2}$ and $5 \sim 12 \%$ of $\mathrm{CH}_{4}$, respectively. Meanwhile, the gas flow ranges from 6 to 700 liter/hour. This variation was probably due to the migration of bubbles in the mud pool that could substantially change the total amount of gases coming into the collecting funnel with time (Yang and others 2004). Supposing the funnel collects about $1 / 4$ bubbling gases of the CL mud-pool, and the average flow rate and gas compositions from June 25, 2002 to July 8 , 2002 are close to the annual average values. The amount of gases exhaling from the mud-pool can be estimated to be about 1.4 ton/year for $\mathrm{CH}_{4}$ and 28 ton/year for $\mathrm{CO}_{2}$, respectively.

Summary of measurement and estimates of methane flux from major vents of representative mud volcanoes and seepages in Taiwan is shown in Tab. 2. The measured gas flux from the major vents range from $0.08-9.40 \mathrm{~kg} / \mathrm{day}$, which is comparable with that measured from the mud volcanoes of Sicily, Italy (Etiope and others 2002). The estimated total methane exhaling from major vents of the studied areas is ca. 29 ton/year. Note that this amount is the minimum estimation during the quiescent period without eruption. Meanwhile, diffuse soil leakage around the vents could be up to ten to twenty times the amount of vent exhalation (Etiope and others 2002). Further, precise measurement of the gas flux, including vents and soil diffusion, are needed to better estimate the methane flux from the mud volcanoes in Taiwan.

\section{Conclusions}

1. Most gases emitting from active mud volcanoes in Taiwan are methane-dominant. However, unusual $\mathrm{CO}_{2}-$ dominant and nitrogen-excess gases are exhaling from the CL and LS mud volcanoes, respectively.

2. Multiple gas reservoirs are proposed to account for the gas compositions of mud volcanoes in southwestern Taiwan. One is a $\mathrm{CO}_{2}$-dominated gas reservoir at 


\section{Table 2}

Measurements and estimates of methane flux from mud volcanoes and seepages in Taiwan

\begin{tabular}{|c|c|c|c|c|c|c|}
\hline Location & Area $\left(m^{2}\right)^{a}$ & No of vents & $\begin{array}{c}\text { Flow rate } \\
\text { (liter/min) }\end{array}$ & $\begin{array}{c}\mathrm{CH}_{4} \text { concen- } \\
\text { tration } \\
(\mathrm{vol} \%)^{\mathrm{b}}\end{array}$ & $\begin{array}{c}\text { Output of } \\
\text { measured } \\
\text { vent }(\mathrm{kg} / \\
\text { day) }\end{array}$ & $\begin{array}{l}\text { Estimated } \\
\text { total output } \\
\text { of the area } \\
\text { (ton/year) }\end{array}$ \\
\hline $\mathrm{CL}$ & 100 & 8 & 8.91 & 11.5 & 0.98 & 1.43 \\
\hline SHTY & 9 & 9 & 0.15 & 94.7 & 0.13 & 0.97 \\
\hline KZL & $3^{c}$ & 2 & $0.10^{\mathrm{d}}$ & 84.0 & 0.08 & 0.04 \\
\hline DKS & 900 & 6 & $10.0^{\mathrm{d}}$ & $98.0^{\mathrm{e}}$ & 9.40 & 13.72 \\
\hline SKS & 300 & 4 & 1.20 & 98.0 & 1.13 & 1.03 \\
\hline YNH & 400 & 5 & $1.50^{\mathrm{d}}$ & $95.0^{\mathrm{f}}$ & 1.37 & 1.66 \\
\hline SYNH & 442 & 10 & 1.52 & 95.0 & 1.39 & 1.68 \\
\hline WSD & 6,100 & 7 & 1.39 & 99.2 & 1.32 & 4.81 \\
\hline YC & 31.5 & 8 & 1.16 & 98.5 & 1.10 & 0.67 \\
\hline GSP & 5,200 & 1 & 3.33 & 95.7 & 3.06 & 1.12 \\
\hline $\mathrm{CH}$ & 700 & 8 & $0.15^{\mathrm{d}}$ & 94.7 & 0.14 & 0.33 \\
\hline LS & 900 & 10 & 0.20 & 93.0 & 0.18 & 0.65 \\
\hline \multirow[t]{2}{*}{$\mathrm{DK}$} & 900 & 8 & $0.20^{\mathrm{d}}$ & 98.0 & 0.19 & 0.69 \\
\hline & & & & & $\begin{array}{c}\text { Total } \mathrm{CH}_{4} \\
\text { output }\end{array}$ & 28.8 \\
\hline
\end{tabular}

\footnotetext{
a The area is covered with mud and no vegetation;

${ }^{\mathrm{b}}$ Composition after air correction (Table 1);

${ }^{c}$ Muddy hot springs well;

${ }^{d}$ Visual estimation;

e Assuming the gas composition is similar with those emitted from SKS mud volcanoes;

${ }^{\mathrm{f}}$ Assuming the gas composition is similar with those emitted from SYNH mud volcanoes
}

a deeper depth; another is a $\mathrm{CH}_{4}$-dominated at a shallower depth.

3. According to the data of continuous measurement, there are ca. 1.4 tons of $\mathrm{CH}_{4}$ and 28 tons of $\mathrm{CO}_{2}$ annually emitting into atmosphere from the CL mud pool.

4. The estimated total methane exhaling from major vents of mud volcanoes in Taiwan is ca. 29 ton/year, which is the minimum estimation during the quiescent period.

Acknowledgements The authors wish to thank Ms P.S., Hsieh, Mrs. N.T. Liu, R.H. Tsai, H.H. Ho, J.H. Jiang and B.W. Lin for helping in sample collection and analysis during different periods of this study since 1999. The authors also thank Dr. G. Etiope for efficient handling of the manuscript and much encouragement. Improvements in the manuscript were made by anonymous reviewers. This study was partly financially supported by the National Science Council (NSC90-2116-M-002-031; NSC92-2116M-002-003-/TFY) and the Central Geological Survey, Taiwan, R.O.C.

\section{References}

Chang CP, Angelier J, Huang CY (2000) Origin and evolution of a melange: the active plate boundary and suture zone of the Longitudinal Valley, Taiwan. Tectonophys 325:43-62

Chow J, Lee JS, Liu CS, Lee BD, Watkins JS (2001) A submarine canyon as the cause of a mud volcano: Liuchieuyu Island in Taiwan. Mar Geol 176:55-63

Dimitrov LI (2002) Mud volcanoes-the most important pathway for degassing deeply buried sediments. Earth-Sci Rev 59:49-76

Etiope G, Klusman RW (2002) Geologic emissions of methane to the atmosphere. Chemosphere 49:777-789

Etiope G, Caracausi A, Favara R, Italiano F (2002) Methane emission from the mud volcanoes of Sicily (Italy). Geophys Res Lett 29:14,340-14,343
Gieskes JM, You CF, Lee T, Yui TF, Chen HW (1992) Hydrogeochemistry of mud volcanoes in Taiwan. Acta Geol Taiwan 30:79-88

Huang CY, Wu WY, Chang CP, Tsao S, Yuan PB, Lin CW, Xia KY (1997) Tectonic evolution of accretionary prism in the arc-continent collision terrane of Taiwan. Tectonophys 281:31-51

Hsieh PS (2000) The gas sources of hot springs and mud volcanoes in Taiwan. MS thesis, Inst. Geosciences, National Taiwan Univ., 77 pp (in Chinese with English abstract)

Hsieh S (1972) Subsurface geology and gravity anomalies of the Tainan and Chungchan structures of the coastal plain of SW Taiwan. Petrol Geol Taiwan 10:323-338

Judd A, Davies G, Wilson J, Homes R, Baron G, Bryden L (1997) Contribution to atmospheric methane by natural seepages on the UK continental shelf. Mar Geol 137:165-189

Judd AG, Hovland M, Dimitrov LI, Gil SG, Jukes V (2002) The geological methane budget at continental margins and its influence on climate change. Geofluids 2:109-126

Kopf AJ (2002) Significance of mud volcanism. Rev Geophys 40(2):1,005 doi:10.1029/2000RG000093

Kopf AJ (2003) Comment on the paper "Methane emission from the mud volcanoes of Sicily (Italy)" by Etiope et al. Geophys Res Lett 30(2), doi:10.1029/2000GL015821

Milkov AV (2000) Worldwide distribution of submarine mud volcanoes and associated gas hydrates. Mar Geol 167:29-42

Milkov AV, Sassen R, Apanasovich TV, Dadashev FG (2003) Global gas flux from mud volcanoes: A significant source of fossil methane in the atmosphere and the ocean. Geophys Res Lett 30(2):1,037 doi:10.1029/2002GL016358

Liu CS, Huang IL, Teng LS (1997) Structural features off southwestern Taiwan. Mar Geol 137:305-319

Shih TT (1967) A survey of the active mud volcanoes in Taiwan and a study of their types and the character of the mud. Petrol Geol Taiwan 5:259-311

Teng LS (1990) Geotectonic evolution of late Cenozoic arc-continent collision in Taiwan. Tectonophys 183:57-76

Wang S, Hsu ML, Yang CF (1988) Mud volcanoes of Taiwan. Annual Taiwan Museum 31:31-49 (in Chinese with English abstract) 
Yang TF, Chen CH, Tien RL, Song SR, Liu TK (2003a) Remnant magmatic activity in the Coastal Range of East Taiwan after arccontinent collision: fission-track date and ${ }^{3} \mathrm{He} /{ }^{4} \mathrm{He}$ ratio evidence. Radiat Meas 36:343-349

Yang TF, Chou CY, Chen CH, Chyi LL, Jiang JH (2003b) Exhalation of radon and its carrier gases in SW Taiwan. Radiat Meas 36:425-429

Yang TF, Jiang JH, Chen CH, Chou CY, Chyi LL, Song SR, Lee CY, Lee M, Lin CW, Lin CC, Liu TK (2004) Seismo-geochemical variations in SW Taiwan: multi-parameter automatic gas monitoring results. Pure and Applied Geophysics (in review)
Yassir NA (1987) Mud volcanoes: evidence of neotectonic activity. Mem Geol Soc China 9:513-524

Yeh GH (2003) Geochemistry and sources of mud-volcano fluids in Taiwan. MS thesis, Inst. Oceanography, National Taiwan Univ., $61 \mathrm{pp}$ (in Chinese with English abstract)

Yeh GH, Yang TF, Chen JC, Chen YG, Song SR (2004) Fluid geochemistry of mud volcanoes in Taiwan. In Martinelli, G. and Panahi, B. (eds) NATO Advanced Research Workshop, Mud volcanism, Geodynamics and Seismicity. Kluwer Academic Pub. (in press) 